\title{
Expected Radiation Effects in Plutonium Immobilization Ceramic
}

\author{
Richard A. Van Konynenburg
}

September 1997

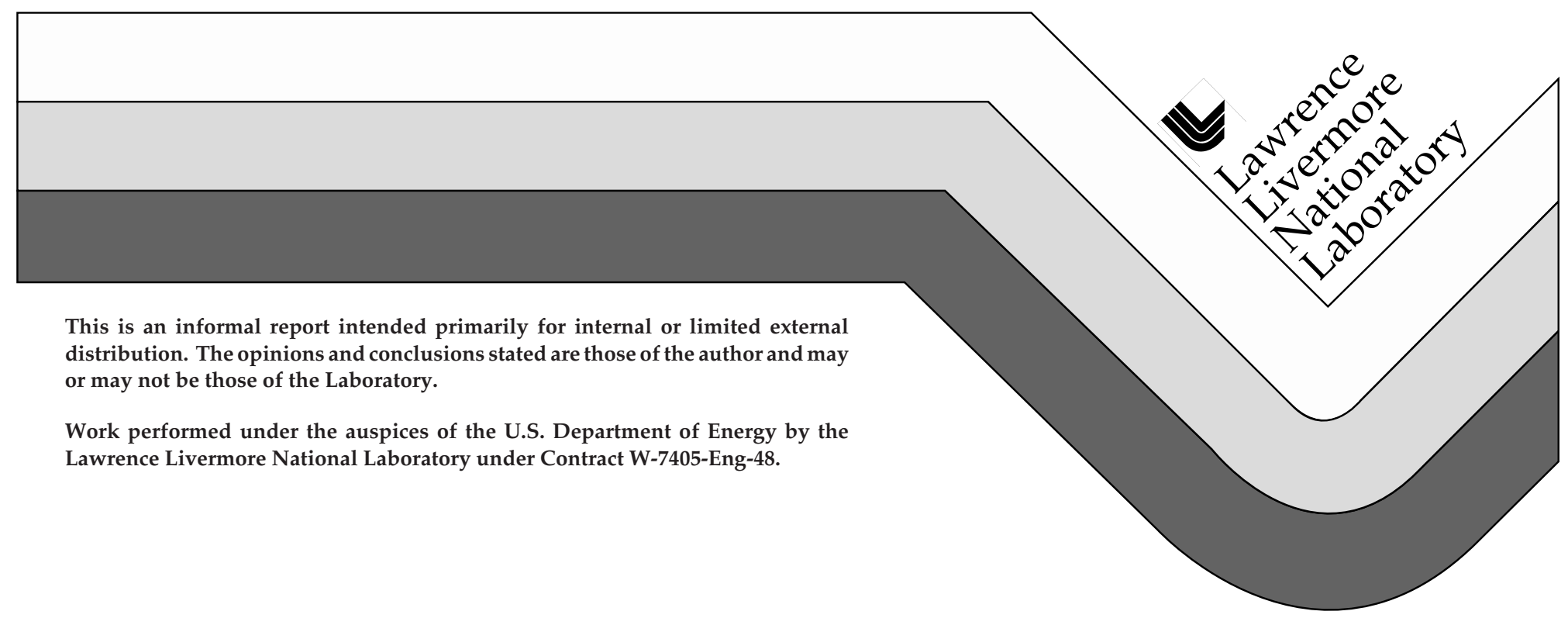




\section{DISCLAIMER}

This document was prepared as an account of work sponsored by an agency of the United States Government. Neither the United States Government nor the University of California nor any of their employees, makes any warranty, express or implied, or assumes any legal liability or responsibility for the accuracy, completeness, or usefulness of any information, apparatus, product, or process disclosed, or represents that its use would not infringe privately owned rights. Reference herein to any specific commercial product, process, or service by trade name, trademark, manufacturer, or otherwise, does not necessarily constitute or imply its endorsement, recommendation, or favoring by the United States Government or the University of California. The views and opinions of authors expressed herein do not necessarily state or reflect those of the United States Government or the University of California, and shall not be used for advertising or product endorsement purposes.

This report has been reproduced directly from the best available copy.

Available to DOE and DOE contractors from the Office of Scientific and Technical Information

P.O. Box 62, Oak Ridge, TN 37831

Prices available from (615) 576-8401, FTS 626-8401

Available to the public from the

National Technical Information Service

U.S. Department of Commerce 5285 Port Royal Rd.,

Springfield, VA 22161 


\section{Expected Radiation Effects in Plutonium Immobilization Ceramic*}

\section{Executive Summary}

The current formulation of the candidate ceramic for plutonium immobilization consists primarily of pyrochlore, with smaller amounts of hafnium-zirconolite, rutile, and brannerite or perovskite. At a plutonium loading of 10.5 weight $\%$, this ceramic would be made metamict (amorphous) by radiation damage resulting from alpha decay in a time much less than 10,000 years, the actual time depending on the repository temperature as a function of time.

Based on previous experimental radiation damage work by others, it seems clear that this process would also result in a bulk volume increase (swelling) of about $6 \%$ for ceramic that was mechanically unconfined. For the candidate ceramic, which is made by cold pressing and sintering and has porosity amounting to somewhat more than this amount, it seems likely that this swelling would be accommodated by filling in the porosity, if the material were tightly confined mechanically by the waste package.

Some ceramics have been observed to undergo microcracking as a result of radiation-induced anisotropic or differential swelling. It is unlikely that the candidate ceramic will microcrack extensively, for three reasons: (1) its phase composition is dominated by a single matrix mineral phase, pyrochlore, which has a cubic crystal structure and is thus not subject to anisotropic swelling; (2) the proportion of minor phases is small, minimizing potential cracking due to differential swelling; and (3) there is some flexibility in sintering process parameters that will allow limitation of the grain size, which can further limit stresses resulting from either cause.

The metamictization process will convert the original, ordered titanium-oxygen polyhedral framework of the ceramic to an aperiodic, random network of corner-sharing polyhedra in which the titanium has a slightly lower average coordination number. When water in the repository eventually contacts the metamict ceramic, there will likely be leaching of a small amount of non-network ions $(\mathrm{Ca}, \mathrm{U}, \mathrm{Gd}$, and $\mathrm{Pu}$, in the order of decreasing expected release) from a thin layer at the surface, based on 
studies by others on natural actinide-containing mineral analogs. The titanium-oxygen network in this thin surface layer will be transformed to anatase, and the long-term release behavior of the ceramic will likely then be governed by the behavior of this layer. In the mid-pH range, titanium oxide is known to be very insoluble in water. For example, the rutile form of titanium oxide has a measured solubility in water at room temperature between $\mathrm{pH} 9$ and $\mathrm{pH} 10$ of $\underline{10}^{-9}$ molal.

Very limited experimental data by others suggests that the process of metamictization may increase the release rate of plutonium from the ceramic in contact with water by a factor of one to one and one-half orders of magnitude.

Another reference point for long-term behavior is the observed condition of samples of uranium- and thorium-containing, high-titanium natural pyrochlores, which have been rendered metamict and have achieved measured ages up to a billion years. These samples are found to have substantially retained their actinides, despite their great ages. This is consistent with the low solubility of titanium oxide. 


\section{Expected Radiation Effects in Plutonium Immobilization Ceramic}

\section{Introduction}

One of the two candidate materials under development for the immobilization of excess U.S. weapons-grade plutonium is a titanate ceramic (The other is a lanthanide borosilicate glass). It is desirable that any immobilization form be able to retain the plutonium, as well as its uranium decay product and the designed-in neutron absorbers, for very long times under conditions expected in geologic disposal. This is important both to prevent nuclear criticality and to prevent release of plutonium to the environment in order to maintain radiological safety.

Because an immobilization form will contain a fairly high loading of plutonium to minimize costs, and because the dominant isotope in weapons-grade plutonium undergoes alpha decay with a half-life of 24,100 years, the form will be subject to a high rate and a high total amount of radiation damage as a result of internal alpha decay. It is important that the immobilization form maintain its capability to sequester the plutonium, its uranium decay product, and the neutron absorbers over long periods of time in the presence of this radiation damage. The most important properties in this regard are the dissolution rates of the matrix material and the leach rates of the individual elements of interest when the form is exposed to aqueous solutions.

Two approaches have been used in the past to assess the effects of radiation on ceramic nuclear waste forms: short-duration simulation experiments using actinide doping or external radiation sources (VAN KONYNENBURG, 1983), and comparison to natural mineral analogs that have successfully contained uranium and/or thorium undergoing natural radioactive decay over geologic time periods (OVERSBY, 1981; SINCLAIR, 1981; EWING, 1988; LUMPKIN, 1995). While simulation experiments have been planned for the future on the titanate ceramic candidate immobilization form for plutonium, they have not yet been carried out, and programmatic decisions must be made before the results of this work will be available. Fortunately there is a body of relevant experiments reported 
in the literature, as well as observations on relevant natural minerals, from which a great deal has been learned that is directly applicable to the plutonium immobilization problem.

This report has been written to provide a projection of radiation effects in the candidate ceramic on the basis of this past work. The plutonium immobilization ceramic is described first. Then a discussion of alpha decay and its effects on ceramics in general are presented. Next are sections on radiation damage experiments and natural mineral analogs. These are followed by brief reviews of the work on the individual mineral phases. Finally, these data are used to project radiation effects in the plutonium immobilization ceramic.

\section{Description of Plutonium Immobilization Ceramic}

Although minor changes in formulation may yet be made, the current version of the plutonium immobilization ceramic consists primarily of the mineral phase pyrochlore with smaller amounts of hafnium-zirconolite, brannerite or perovskite, and rutile. Some developmental samples have contained small amounts of plutonium oxide, but further refinement of the formulation and processing conditions will probably eliminate this phase. Therefore, its radiation damage behavior is only touched upon briefly in this report.

The pyrochlore phase in the ceramic corresponds to the group of natural minerals of the same name, which have a cubic crystal structure and the generalized formula $\mathrm{A}_{2} \mathrm{VIII}_{\mathrm{B}_{2}} \mathrm{VIX}_{7} \mathrm{IV}$, where $\mathrm{A}$ and $\mathrm{B}$ are cations, $\mathrm{X}$ are anions, and the Roman numerals indicate the coordination numbers of the ions (CHAKOUMAKOS, 1987). In the version of pyrochlore used in the candidate $\mathrm{Pu}$ immobilization ceramic, the A site is occupied by $\mathrm{Ca}, \mathrm{U}, \mathrm{Gd}, \mathrm{Hf}$, and $\mathrm{Pu}$, while the $\mathrm{B}$ site is occupied primarily by Ti. Oxygen is the only anion. This pyrochlore composition is somewhat similar to but more complex than $\mathrm{CaUTi}_{2} \mathrm{O}_{7}$ (DICKSON, 1989), which was used in Synroc-F (KESSON, 1983) and Synroc-FA (SOLOMAH, 1987).

The zirconolite phase in the ceramic corresponds to the natural mineral of the same name, which exists as several polytypoids (BAYLISS, 1989). The aristotype (simplest structure from which the others can be derived) of natural zirconolite is zirconolite-2M, which has a monoclinic 
structure and a general end-member formula $\mathrm{Ca}_{2} \mathrm{VIII}_{\mathrm{Zr}_{2}} \mathrm{VII}^{\mathrm{Ti}}{ }_{3} \mathrm{VI} \mathrm{Ti}^{\mathrm{V}} \mathrm{O}_{14}$, which is usually abbreviated as $\mathrm{CaZrTi}_{2} \mathrm{O}_{7}$. Incorporation of actinides into zirconolite has been described by Vance et al. (VANCE, 1994). In the candidate plutonium-immobilization ceramic, $\mathrm{Zr}$ is completely replaced, and its site is shared by $\mathrm{Hf}, \mathrm{U}, \mathrm{Pu}$, and $\mathrm{Gd}$. An equal amount of $\mathrm{Gd}$ is also found in the $\mathrm{Ca}$ site, thus achieving charge balance. When impurity $\mathrm{Al}$ or $\mathrm{Ga}$ are present, they can be accommodated in the $\mathrm{Ti}$ site to balance $\mathrm{Gd}$ in the $\mathrm{Ca}$ site.

Brannerite has the formula $\mathrm{UTi}_{2} \mathrm{O}_{6}$ and a monoclinic structure (PABST, 1954; PATCHETT, 1960; LEJUS, 1966). It is capable of incorporating Pu, Hf, and $\mathrm{Gd}$.

A small amount of rutile ( $\mathrm{Ti}^{\mathrm{VI}} \mathrm{O}_{2}$, tetragonal) is designed to be present in the ceramic, in order to guarantee Ti-rich conditions during reactive sintering. This avoids Ca-rich conditions, which could lead to less durable minor phases. Hf substitutes for some of the $\mathrm{Ti}$ in the rutile.

Perovskite $\left(\mathrm{Ca} X \mathrm{XITi}_{\mathrm{VI}} \mathrm{O}_{3}\right.$, orthorhombic), when present, can incorporate rare earths and actinides (RINGWOOD, 1988).

As noted, some developmental samples have contained plutonium oxide $\left(\mathrm{PuVIII}_{2} \mathrm{IV}\right.$, cubic), although further refinement of the formulation and processing conditions is expected to eliminate this phase. Other minor phases may be present, depending on impurities in the plutonium feed streams, but they are not expected to contain significant quantities of $\mathrm{Pu}$.

The target overall composition of the plutonium host phase(s) at present (without impurities) is $\left(\mathrm{Ca}_{0.89} \mathrm{Gd}_{0.11}\right)\left(\mathrm{U}_{0.44} \mathrm{Hf}_{0.23} \mathrm{Pu}_{0.22} \mathrm{Gd}_{0.11}\right) \mathrm{Ti}_{2} \mathrm{O}_{7}$. This formulation includes 10.5 weight $\%$ plutonium, and twice as much uranium as plutonium. Hafnium and gadolinium are present in molar amounts equal to that of plutonium to serve as neutron absorbers, and the uranium, principally $238 \mathrm{U}$, serves as a diluent for the fissile $235 \mathrm{U}$ that will be produced by decay of ${ }^{239} \mathrm{Pu}$, thus lowering its effective enrichment.

The ceramic is fabricated by cold pressing and sintering rather than by hot pressing in order to reduce cost and maximize process reliability and safety. This process results in a product density of $90 \%$ or more of the theoretical maximum density of $6.1 \mathrm{~g} / \mathrm{cm}^{3}$. (Although porosity is generally considered to be undesirable in a ceramic intended for structural use, it may be advantageous in this application because the residual porosity may accommodate radiation-induced swelling, which will be discussed further 
below). The grain size is typically one to a few micrometers, depending on sintering time and temperature.

\section{Plutonium Alpha Decay}

Weapons-grade plutonium typically has approximately the following isotopic make-up after its initial production (half-lives are taken from GENERAL ELECTRIC, 1996):

\begin{tabular}{|c|c|c|}
\hline Isotope & Initial Atomic \% & Half-life (years) \\
\hline $238 \mathrm{Pu}$ & 0.03 & 87.7 \\
\hline${ }^{239} \mathrm{Pu}$ & 94. & 24,100 \\
\hline${ }^{240} \mathrm{Pu}$ & 5.27 & 6,560 \\
\hline $241 \mathrm{Pu}$ & 0.5 & 14.4 \\
\hline${ }^{242} \mathrm{Pu}$ & 0.2 & $3.75 \times 10^{5}$ \\
\hline${ }^{241} \mathrm{~A} \mathrm{~m}$ & 0.0 & 432.7 \\
\hline
\end{tabular}

All the plutonium isotopes except ${ }^{241} \mathrm{Pu}$ decay by alpha emission, each decay producing a helium atom (after capture of two electrons) and a long-lived uranium atom having four fewer atomic mass units than its respective parent plutonium isotope. ${ }^{241} \mathrm{Pu}$ undergoes beta decay to produce ${ }^{241} \mathrm{Am}$. The ${ }^{241} \mathrm{Am}$ in turn alpha decays, producing a helium atom and a long-lived ${ }^{237} \mathrm{~Np}$ atom. The cumulative numbers of alpha decays per plutonium atom in a sample of plutonium with this isotopic composition as a function of time can be calculated from the half-lives, and are as shown in the following table. Also shown are the calculated cumulative numbers of alpha decays per gram of ceramic for a ceramic with a 10.5 weight $\%$ loading of plutonium having this isotopic composition. 
Time (years)

Alpha Decays per Pu Atom

$\begin{array}{rc}10 & 3.66 \times 10^{-4} \\ 50 & 1.97 \times 10^{-3} \\ 100 & 4.23 \times 10^{-3} \\ 1,000 & 3.70 \times 10^{-2} \\ 10^{4} & 0.275 \\ 10^{5} & 0.945 \\ 10^{6} & 1.00\end{array}$

Alpha Decays per Gram

$9.6 \times 10^{16}$

$5.2 \times 10^{17}$

$1.1 \times 10^{18}$

$9.7 \times 10^{18}$

$7.2 \times 10^{19}$

$2.5 \times 10^{20}$

$2.6 \times 10^{20}$

Each alpha decay emits an alpha particle in a random direction and a recoiling heavy nucleus in the opposite direction, thus conserving momentum. The average alpha particle energy for this isotopic mix is 5.2 $\mathrm{MeV}$, and the average recoil nucleus energy is $87 \mathrm{keV}$. These are calculated from data given in LEDERER, 1978. The alpha particles have a range of about 10 micrometers (KRANE, 1988), and the recoil nuclei about 50 nanometers (VAN KONYNENBURG, 1983).

\section{Effects of Internal Alpha Decay on Ceramics}

The alpha particles lose energy primarily by ionization and excitation of electrons because of their high initial velocities relative to those of the orbital electrons, but near the end of their ranges some of their energy goes into elastic collisions with nuclei in the ceramic, causing the breaking of bonds and displacement of atoms from their lattice sites. Each alpha particle produces about 120 atomic displacements (VAN KONYNENBURG, 1983). Each displacement constitutes a Frenkel pair, consisting of one interstitial atom and one vacancy. Each recoil nucleus loses energy primarily by atomic collisions, and displaces about 980 atoms from their lattice sites (VAN KONYNENBURG, 1983). These displacements are concentrated along the tracks of the recoil nuclei. (Some authors quote higher numbers of displacements, depending on the values of parameters used in the calculation, but the ratio of the number of displacements for recoil nuclei to those for alpha particles is still generally estimated as about one order of magnitude.) Atomic displacements resulting from beta decay of $\mathrm{Pu}-241$ are negligible in number in comparison to those produced by 
alpha decay of the other isotopes because of the large mass mismatch between the beta particles and the atoms in the ceramic and because much of the Pu-241 will have decayed to Am-241 at the time the ceramic is fabricated.

If a ceramic is an electrical insulator (as is true for the titanates), many of the ionized electrons are trapped in non-equilibrium states, forming electron-hole pairs. However, since titanates have not been found to be subject to displacement of atoms as a result of ionization (a process called radiolysis or ionization damage), the ionization does not have a significant effect on the structure of the ceramic. (Note that some other insulating solids, in particular the alkali halides, quartz, and some silicates, exhibit radiolysis damage, which produces chemical decomposition, in some cases at fairly low doses (HOBBS, 1994)).

In addition to producing atomic displacements, the alpha decay process transmutes all the plutonium nuclei to long-lived uranium nuclei (except for $241 \mathrm{Pu}$, which is transmuted to neptunium, as discussed earlier), and these are probably injected initially mostly into interstitial positions in the crystal lattice, because of their high recoil energy. Each alpha decay also injects a helium atom into the ceramic, which has very low solubility, and is usually trapped in a vacant lattice site, a lower energy configuration than in an interstitial site. Unless the temperature is raised to a significant fraction of the absolute melting point, the helium remains trapped and does not agglomerate into large bubbles.

If the grain size of the ceramic is large compared to the range of the recoil nuclei, as is true in the present case (one to a few micrometers, as compared with tens of nanometers), the rate of atomic displacement in each grain will be essentially proportional to the concentration of plutonium in that grain. In the case of a ceramic having more than one phase, each having a different $\mathrm{Pu}$ concentration, as is true of the $\mathrm{Pu}$ immobilization ceramic, this means that the rate of atomic displacements will be different for each phase.

Once a damage track has formed in a crystalline ceramic as a result of the passage of a recoil nucleus from alpha decay, the displaced atoms are subject to solid state diffusion, which will tend to anneal the damage and restore the crystal structure. The degree to which this occurs in a given case depends on temperature and time, as with any Arrhenius diffusive 
process. In addition, the nature of the original crystal structure is also important. The more topologically complex the structure, and the larger the number of distinguishable cation sites it contains, the smaller the recovery that will occur under a given time-temperature scenario.

For cases in which the damage anneals slowly relative to the rate of production of additional damage, new damage tracks may overlap existing ones, eventually leading to metamictization (amorphization of the crystal structure) (EWING, 1987), as observed by x-ray diffraction, transmission electron microscopy, XAFS and XANES. In such cases, an expansion of the crystal lattice is observed in the early stages of the process, while most of the material still remains crystalline. At higher degrees of damage the crystallinity is lost, and the material eventually undergoes swelling by several percent. The structure of the fully damaged, metamict state appears to be an aperiodic, random network of corner-sharing polyhedra, resembling that of glass, but in a different thermodynamic state than nonirradiated glass. (For example, when silica glass is irradiated, it undergoes a volume contraction of about 3\% to form what has been called the "compacted state of vitreous silica," which is quite different from nonirradiated silica glass.) In forming the metamict structure the longrange order is destroyed, but the short-range order and the primary coordinations of the cations are essentially preserved. (Recent evidence from XANES indicates that the coordination number of titanium in zirconolite changes from predominantly six to predominantly five as the minerals become metamict (FARGES, 1997).)

If more than one phase is present, adjacent grains may swell at different rates because of different solid state characteristics and/or different plutonium concentrations; this is termed differential swelling. If a particular phase has a noncubic crystal structure, it can swell anisotropically. Differential and anisotropic swelling have been found to cause grain separation or microcracking in some ceramics. The tendency to form microcracks can be countered by the choice of single-phase or nearly single-phase ceramics having cubic crystal structures to minimize both anisotropic and differential swelling, and/or by keeping the grain size small (of the order of one micrometer or less), thus limiting the magnitude of the swelling-produced stresses. In the present case, the cubic mineral 
pyrochlore has been selected to dominate the ceramic, and the grain size can be limited to some extent by choice of appropriate sintering conditions.

\section{$\underline{\text { Radiation Damage Experiments }}$}

A considerable body of experimental work has been reported in the literature concerning the effects of radiation on ceramics in general, and on the particular phases of interest for the plutonium immobilization ceramic. Radiation effects on ceramics in general have been reviewed (CLINARD, 1986a; HOBBS, 1994). Radiation effects on nuclear waste forms, including most of the phases of current interest, were reviewed recently by Ewing, Weber, and Clinard (EWING, 1995). Pertinent references from these reviews that apply to the candidate ceramic are cited below.

Because it is desirable to predict the behavior of the ceramic for long times on the basis of relatively short-term laboratory experiments, radiation damage researchers make use of methods that will increase the damage rate several orders of magnitude over what will occur in the actual waste form. This raises the question of whether such experiments constitute accurate simulations, i.e., whether there is a significant damage rate effect. This question has been examined by several researchers for each phase of interest, since their annealing rates differ. For pyrochlore and zirconolite, the annealing rates have been found to be very slow, but measurable using samples in the billion-year age range (LUMPKIN, 1995).

The type of radiation used in the experiments is also important. The most accurate simulation of the effects of internal alpha decay of plutonium is made by the method of actinide doping, in which a shorter half-life actinide, usually ${ }^{238} \mathrm{Pu}$ (87.7 years) or ${ }^{244} \mathrm{Cm}$ (18.1 years), is incorporated into the samples by ionic substitution when they are initially fabricated. Other approaches have included ion bombardment, which is suitable only for samples thinner than a few tens of nanometers, but is nevertheless useful for determining the progress of metamictization, and neutron irradiation, which produces a different physical distribution of displacements (particularly in polyphase ceramics) and a different recoil energy spectrum from internal alpha decay of dissolved actinides, but is capable of uniformly irradiating thick samples. 
Selected radiation damage experiments are discussed below for each crystalline phase of interest. The observed phenomena have included the state of order of the material, microstructure, lattice parameter changes resulting from internal stress, volume expansion or swelling, stored energy, microcracking, fracture toughness, hardness, annealing behavior and dissolution or leaching. This brief review focuses on those properties of importance for the plutonium immobilization application, principally metamictization, swelling, microcracking, dissolution, and leaching.

\section{Natural Analog Mineral Studies}

One of the major advantages of the use of ceramics for immobilizing plutonium is that it is possible to select ceramic phases that have very high chemical durability, as evidenced by the fact that they are found in nature as minerals that have successfully retained uranium and/or thorium for times of the order of billions of years, even though the minerals have been rendered metamict by the alpha decay of these elements and their progeny (EWING, 1988). The ages can be determined by radioactive dating. The ages determined by different methods can also be compared to see if they are concordant, and thus whether the various members of the radioactive decay chains have been retained in the material. In addition, the samples can be characterized by a range of techniques to determine whether geochemical alteration has occurred.

Because of the much longer half-lives of the uranium and thorium isotopes found in naturally occurring minerals than the plutonium halflives given above, the dose rates in natural samples are orders of magnitude lower than in the plutonium immobilization ceramic. The significance of this depends again on the rate of annealing for a particular mineral phase. As noted above, the major phases of interest exhibit extremely slow annealing, which tends to make the damage process independent of the damage rate. In any case, by the use of natural mineral studies in combination with laboratory radiation damage experiments, the anticipated dose rate for the plutonium immobilization ceramic can be bracketed.

Another point that should be mentioned is that the chemical compositions of natural minerals having the crystal structures of interest in 
some cases may differ substantially from those of the corresponding phases in the planned ceramic for plutonium immobilization. However, the radiation damage behavior for minerals with a given crystal structure has been found to be similar for the range of composition variations found to occur.

A final issue of importance is that the chemical and thermal environments experienced by the natural minerals over their lifetimes are not known in detail, and must be inferred from their geologic milieu and from what can be learned by examining them. Nevertheless, natural analog minerals have provided valuable insights into the long-term behavior of crystalline materials subjected to radiation damage. This type of information is not available for proposed immobilization forms that are not found as actinide hosts in nature.

\section{Consideration of Individual Mineral Phases}

\section{Pyrochlore}

Wald, Weber et al. (WALD, 1982; 1984; WEBER, 1985; 1986) studied the effects of internal alpha decay on 3 wt. $\%{ }^{244} \mathrm{Cm}$-doped $\mathrm{Gd}_{2} \mathrm{Ti}_{2} \mathrm{O}_{7}$ pyrochlore. The material was made by cold-pressing and sintering at $1400^{\circ} \mathrm{C}$ for 46 hours, and had a porosity of $14.2 \%$. The grain size was not reported. The pyrochlore became fully amorphous at a dose of 1.7 to $1.9 \mathrm{x}$ $10^{25}$ alpha decays $/ \mathrm{m}^{3}$ (2.9 to $3.2 \times 10^{18}$ alpha decays per gram) at an estimated storage temperature of $50^{\circ} \mathrm{C}$. It underwent bulk swelling, exponentially approaching a saturation value of 5.1 volume \%. It reached $1-(1 / \mathrm{e})$ of this saturation value at a dose of $9 \times 10^{24}$ alpha decays per $\mathrm{m}^{3}$ (1.5 x $10^{18}$ alpha decays per gram). For material made with a porosity of $9.5 \%$, the swelling saturated at $5.6 \%$. No significant microcracking was observed as a result of the swelling and amorphization up to a dose of $2.3 \mathrm{x}$ $10^{25}$ alpha decays per $\mathrm{m}^{3}\left(3.7 \times 10^{18}\right.$ alpha decays per gram).

Wald and Weber measured the effects of alpha decay on the dissolution kinetics of the pyrochlore in distilled water at $90^{\circ} \mathrm{C}$ for 14 days, by comparing the behavior of fully damaged material having an accumulated dose of $2.9 \times 10^{25}$ alpha decays per $\mathrm{m}^{3}$ (or $4.7 \times 10^{18}$ alpha decay per gram) to that of material that had been fully damaged and then annealed back to the crystalline state by heating to $1100^{\circ} \mathrm{C}$ for 12 hours. 
This approach insured that the overall chemical compositions of the samples and the radiolytic conditions in the leachant were the same for the two cases. Their results are reproduced in the following table:

\begin{tabular}{|c|c|c|c|c|c|c|}
\hline \multirow[t]{2}{*}{$\begin{array}{l}\text { Sample } \\
\text { Condition }\end{array}$} & \multirow[t]{2}{*}{$\frac{\text { Percent weight loss }}{\text { of sample }}$} & \multicolumn{4}{|c|}{ Normalized elemental } & \multirow[t]{2}{*}{$\frac{\text { Final }}{\mathrm{pH}}$} \\
\hline & & $\underline{\mathrm{Gd}}$ & $\underline{\mathrm{Ti}}$ & ${ }^{244} \underline{\mathrm{Cm}}$ & $240 \underline{\mathrm{Pu}}$ & \\
\hline Crystalline & 0.02 & $\mathrm{ND}^{*}$ & $<0.02$ & 0.01 & 0.12 & 5.6 \\
\hline Amorp & 0.05 & $\mathrm{ND}$ & $<0.02$ & 0.17 & 593 & 5.3 \\
\hline
\end{tabular}

$(* \mathrm{ND}=$ not determined $)$

As can be seen, the overall weight loss of the amorphous sample, though still small, was a factor of 2.5 larger than that of the crystalline sample. Because the $\mathrm{Ti}$ concentration in the leachate was found to be below the detection limit in both cases, it appears that either titanium was solubilitylimited or that the titanium oxide framework resisted dissolution, and continued to do so after amorphization. This is consistent with the extremely low solubility of $\mathrm{TiO}_{2}$ in water. The results for the non- $\mathrm{TiO}_{2}$ framework species $\mathrm{Cm}$ and $\mathrm{Pu}$, on the other hand, show increases by factors of 17 and 49, respectively, indicating that they were not as tightly bound or as well protected from leaching in the case of the amorphous material. Their concentrations are also consistent with the fact that their solubilities under the prevailing $\mathrm{pH}$ and redox conditions, although low, are not as limited as that of titanium. The observation that the $\mathrm{Pu}$ exhibited a larger increase in release than the $\mathrm{Cm}$ is probably related to the fact that much of it was born as recoil nuclei from alpha decay after the ceramic was made, and was thus injected into the material in a highly irreversible fashion, ending up in positions in the amorphous sample that were likely less tightly bound than those it occupied in the annealed, crystalline sample after solid-state diffusion took place. This same rationale has been applied to explain the leaching results for natural minerals, which show that the isotopes of $U$ and $T h$ that result from alpha decay exhibit higher releases than corresponding isotopes of the same elements that were present when the minerals formed (EYAL, 1982). 
Clinard et al. studied the behavior of "238 Pu-substituted zirconolite," which in fact has the cubic structure of pyrochlore (CLINARD, 1984b; 1985; 1986b; 1991; FOLTYN, 1985). They fabricated the material by coldpressing and sintering for 16 to 24 hours at temperatures of 1350 to $1400^{\circ}$ C. The grain sizes were 10 to 20 micrometers, and the porosity was 7 to $10 \%$. The volume fraction of minor phases was 5 to $12 \%$. They found that the material, when stored under ambient conditions at about $75^{\circ} \mathrm{C}$, became metamict and swelled to a saturation value of 5.4 bulk volume\% at a dose of 2 to $3 \times 10^{25}$ alpha decays per $\mathrm{m}^{3}$ ( 3 to $5 \times 10^{18}$ alpha decays per gram). No radiation-induced microcracking was observed. When stored at $300^{\circ} \mathrm{C}$ the material swelled more slowly, and the swelling saturated at $4.3 \%$. When stored at $600^{\circ} \mathrm{C}$ the material remained crystalline and swelled only $0.4 \%$. No leach testing was performed on this material, but it is significant to note that the saturation value of the swelling at the ambient storage temperature was equal to that of the $\mathrm{Cm}$-doped $\mathrm{Gd}_{2} \mathrm{Ti}_{2} \mathrm{O}_{7}$ pyrochlore studied by Weber et al., i.e. 5.4 compared to 5.1 to 5.6\%. This suggests that the radiation damage behavior of pyrochlore is not very sensitive to its chemical composition, at least for the compositions used.

Natural pyrochlore mineral samples have received extensive study, particularly by Lumpkin, Greegor, Ewing, and co-workers (GREEGOR, 1985a; 1985b; 1987; LUMPKIN, 1980; 1985; 1986a; 1986b; 1986d; 1987; 1988a; $1988 b ; 1989 ; 1992 ; 1994 ; 1995 ; 1996)$. Lumpkin and Ewing analyzed alpha-decay damage in pyrochlores having a wide range of chemical compositions, from 15 locations, with ages ranging up to 1.4 billion years. They also studied geochemical alteration of large numbers of samples from a variety of locations classified in the pyrochlore, microlite, and betafite subgroups of the pyrochlore group, with ages up to 1.3 billion years. They found that the mean life for an alpha recoil damage track in crystalline pyrochlore material is limited by annealing to about 100 million years at ambient geologic temperatures. This, together with their high actinide contents, accounts for the observation that most natural actinide-bearing pyrochlore minerals are found in the metamict state.

The pyrochlore phase in the $\mathrm{Pu}$ immobilization ceramic is most similar to natural minerals of the betafite subgroup (MAZZI, 1983). As noted earlier, the pyrochlore minerals have a cubic crystal structure and the general formula $\mathrm{A}_{2} \mathrm{~B}_{2} \mathrm{X}_{7}$, where $\mathrm{A}$ represents large cations, $\mathrm{B}$ consists of 
small cations, and $\mathrm{X}$ represents anions. The betafite subgroup is high in $\mathrm{Ti}$, with $2 \mathrm{Ti}$ being greater than or equal to $\mathrm{Nb}+\mathrm{Ta}$ for the $\mathrm{B}$-site cation population.

Lumpkin and Ewing examined betafite pyrochlores from nine locations, all of which were metamict, having received doses of more than 3 x $10^{20}$ alpha decays per gram. Some of them had ages of 550 million and 1 billion years. Minerals of the betafite subgroup were found to have undergone some secondary alteration, apparently by relatively low temperature and relatively acidic groundwater having low activities of $\mathrm{Na}$, $\mathrm{Ca}$, and F. Although the precise conditions of alteration could not be determined, the observed secondary phases and host-rock alteration were judged to be consistent with near-surface weathering processes at temperatures $<100^{\circ}$, resulting in increased concentrations of $\mathrm{Fe}, \mathrm{Sr}, \mathrm{Ba}, \mathrm{K}$, and $\mathrm{Al}$ in the minerals. The first stage of these processes was found to involve hydration and leaching of $\mathrm{F}, \mathrm{Na}, \mathrm{Ca}$, and $\mathrm{O}$ from the minerals, but the $\mathrm{U}$ and $\mathrm{Th}$ contents remained relatively constant.

For material that had undergone more extreme leaching, the betafite had altered to liandratite + rutile + uranpyrochlore. (Both liandratite and uranpyrochlore are uranium-containing minerals.) In these cases some uranium was lost. They found, however, that the least mobile A-site cations were the $3+$ oxidation-state lanthanide rare earth elements, $\mathrm{Th}^{4+}$, and $\mathrm{U}^{4+}$, and that the rate of ion exchange exceeded the total dissolution rate, governed primarily by the stability of the octahedral framework when occupied by $\mathrm{Nb}$, Ta, and $\mathrm{Ti}$.

Lumpkin and Ewing concluded that actinides were effectively retained by microlite, pyrochlore, and most betafite subgroup samples for geological time periods up to 1.4 billion years. It is significant to note that their results again point to the importance of the Ti-containing framework in resisting dissolution, even after the crystal structure has been rendered amorphous, as was suggested by the experiments of Weber et al. on synthetic pyrochlore.

\section{Zirconolite}

Zirconolite is the principal actinide host phase of the high-level waste ceramics Synroc B, Synroc C, and Synroc D, (RINGWOOD, 1988; RYERSON, 1983) and has thus been the subject of considerable radiation-damage 
study (VAN KONYNENBURG, 1983; RINGWOOD, 1988; REEVE, 1991; SMITH, 1993; JOSTSONS, 1994).

Wald et al. (WALD, 1982) performed radiation damage studies on 3 wt. \% ${ }^{244} \mathrm{Cm}$-doped $\mathrm{CaZrTi}_{2} \mathrm{O}_{7}$ zirconolite. The material was made by coldpressing and sintering at $1325^{\circ} \mathrm{C}$ for 40 hours. The porosity was $10.4 \%$. The grain size was not reported. The swelling was observed by $\mathrm{x}$-ray diffraction to be anisotropic, and it saturated at 6.0 bulk volume $\%$, reaching $(1-1 / \mathrm{e})$ of this value at a dose of $1.0 \times 10^{25}$ alpha decays per $\mathrm{m}^{3}\left(2.5 \times 10^{18}\right.$ alpha decays per gram). Material with a lower porosity (5.2\%) swelled to a saturation value of $6.5 \%$. The material was fully metamict at a dose of 2.1 to $2.3 \times 10^{25}$ alpha decays per $\mathrm{m}^{3}$ (5.2 to $5.7 \times 10^{18}$ alpha decays per gram). No microcracking was observed, in spite of the anisotropic swelling. This may have been the result of small grain size, but this cannot be confirmed, since the grain size was not specified for the samples examined for microcracking. Dissolution testing was performed for 14 days in $90^{\circ} \mathrm{C}$ distilled water, as for pyrochlore. A comparison of the results for fully amorphous zirconolite and for material that was made fully amorphous and then annealed at $1100^{\circ} \mathrm{C}$ for 12 hours to restore its crystallinity is reproduced as follows:

\begin{tabular}{|c|c|c|c|c|c|c|}
\hline \multirow{3}{*}{$\begin{array}{l}\text { Sample } \\
\text { Condition }\end{array}$} & \multicolumn{2}{|c|}{ Percent weight loss } & \multicolumn{3}{|c|}{ Normalized elemental } & \multirow{2}{*}{$\frac{\text { Final }}{\mathrm{pH}}$} \\
\hline & of sample & & mass & $\operatorname{loss}(g$ & & \\
\hline & & $\underline{\mathrm{Ca}}$ & $\underline{\mathrm{Ti}}$ & ${ }^{244} \mathrm{Cm}$ & $240 \underline{\mathrm{Pu}}$ & \\
\hline Cryst & 0.02 & 0.72 & $<0.02$ & 0.001 & 0.02 & 6.4 \\
\hline Amor 1 & 0.05 & 5.99 & $<0.02$ & 0.001 & 0.22 & 7.3 \\
\hline
\end{tabular}

As for pyrochlore, the overall weight loss increased by a factor of 2.5 as a result of the alpha decay. Ca release increased by a factor of 8.3 , and $\mathrm{Pu}$ by a factor of 11. The concentration of $\mathrm{Cm}$ in the solution was believed to be solubility-limited in the $\mathrm{pH}$ range of these experiments. Again, the $\mathrm{Ti}$ concentration in solution was below the limit of detection, owing to its low solubility. As for pyrochlore, it appears that the titanium oxide framework maintained its chemical durability even after amorphization, while the nonnetwork elements, in this case the $\mathrm{Ca}$ and $\mathrm{Pu}$, became more leachable. Also as for the pyrochlore work, it should be noted that much of the $240 \mathrm{Pu}$ resulted from alpha decays that occurred after the ceramic was formed, 
and thus was probably injected into less well bound configurations in the amorphous sample, making it more leachable.

Clinard et al. fabricated a zirconolite-based ceramic containing 5 mole $\%{ }^{238} \mathrm{PuO}_{2}$ for radiation damage study (CLINARD, 1984a). This material was cold-pressed and sintered for 24 hours at $1350^{\circ} \mathrm{C}$. It was found to consist of a monoclinic zirconolite matrix containing 20 vol. \% pyrochlore, 7 vol. \% rutile, and a lesser amount of an unidentified, Pu-bearing, low-Ca phase. The porosity was $9 \%$. and the grain size was about 10 micrometers. The concentration of $\mathrm{Pu}$ was about twice as high in the pyrochlore as in the zirconolite. The zirconolite was saturated with $\mathrm{Pu}$, at about 0.15 moles per formula unit.

The material was observed to become x-ray amorphous in 500 days, at a dose of $1.3 \times 10^{25}$ alpha decays per $\mathrm{m}^{3}$ (3.0 x $10^{18}$ alpha decays per gram). The swelling saturated at $5.5 \%$ at 800 days, corresponding to a dose of $2.1 \times 10^{25}$ alpha decays per $\mathrm{m}^{3}$ ( $4.8 \times 10^{18}$ alpha decays per gram). This material exhibited microcracking, beginning at 128 days, observed to be generalized at 202 days, and reaching its maximum at 364 days. After this time, little change occurred in the crack pattern. The samples maintained their macroscopic mechanical integrity, and did not disintegrate into powder. No leach testing was performed.

The metamictization and swelling behavior of this material is seen to be fairly similar to that observed by Wald et al for the $\mathrm{Cm}$-doped material. However, the presence of significant microcracking is an important difference. Clinard et al. explained this observation in terms of the differential swelling between the zirconolite and the pyrochlore, which sweled faster than the zirconolite because of its higher $\mathrm{Pu}$ concentration. Eventually, the swelling of the pyrochlore began to saturate, and the zirconolite swelling caught up, because they were approaching approximately the same saturation value of swelling, thus reducing the stresses and halting the cracking. The cracking that resulted from differential swelling in this material was no doubt exacerbated by the large grain size and by the fact that the faster swelling phase was surrounded by the slower swelling matrix phase, thus setting up a condition that maximized tensile stresses in the zirconolite. It is well known that brittle materials in general are weaker in tension than in compression. 
Hough and Marples also performed actinide doping experiments on zirconolite, using 4 wt. $\%{ }^{244} \mathrm{Cm}$ or up to 10.4 wt. $\%{ }^{238} \mathrm{Pu}$, and observed saturation of swelling at 4 to $7 \%$ at doses of 5-10 x 1018 alpha decays per gram at $25^{\circ} \mathrm{C}$ with no microcracking. Their material is believed to have been of finer grain size than that of Clinard et al.

Ion bombardment experiments have also been performed on zirconolite (KARIORIS, 1982; EWING, 1992; WEBER, 1992; WHITE, 1995; SMITH, 1996). They have assisted in determining the dose at which metamictization occurs, and are essentially consistent with the actinide doping studies.

Natural samples of zirconolite are relatively rare, but nevertheless several have been characterized (OVERSBY, 1981; SINCLAIR, 1981; EWING, 1983; LUMPKIN, 1986c; 1994; 1995; HART, 1996). Lumpkin et al. found that the mean lifetime of a recoil damage track in crystalline zirconolite is about a factor of two to five longer than in pyrochlore. The transition to the metamict state occurs at doses of $10^{18}$ to $10^{19}$ alpha decays per gram. For metamict samples of ages up to 550 million years, the products of the decay of uranium and thorium to lead were generally retained, within the precision of mass spectrometric measurements (OVERSBY, 1981). The oldest known metamict natural zirconolite (2.5 billion years old) showed evidence of aqueous alteration, but it retained zirconium, thorium, uranium, and the lanthanide rare earth elements.

\section{Brannerite}

Brannerite "occurs chiefly as a primary mineral in pegmatites or as a detrital mineral derived from pegmatites or vein deposits. It has been found in the United States in placer deposits in Custer County, Idaho; at the California mine, Chaffee County and in Gilpin County, Colorado; and in Mono, Plumas, and San Bernardino counties, California. It also occurs in the Blind River district, Ontario, Canada; in the Vosges, France; near Fuenteovejuna, Cordoba, Spain; at Bou-Azzer, Morocco, and at several places in South Australia (ROBERTS, 1974)." Ore deposits containing brannerite have been described (HEINRICH, 1958). Chemical analysis shows the presence of $\mathrm{Ca}$, Fe, Th, and lanthanide rare earths as well as other minor constituents, in addition to the major elements $\mathrm{U}$ and Ti (HEWETT, 1957). Specimens from three locations were found to be essentially metamict, but some showed a 
few weak x-ray diffraction lines (PABST, 1954). Examination of the surface of some of the specimens revealed a fine-grained, polycrystalline crust of anatase that converted to rutile upon heating. Synthesis of brannerite has been described (PATCHETT, 1960; KAIMAN, 1961; LEJUS, 1966). I am not aware of any radiation-damage studies that have been performed on this mineral, or of detailed studies of natural samples.

\section{Perovskite}

Perovskite is one of the main phases in Synroc B, C, and D. Actinide doping studies at Harwell have shown metamictization at a dose of $4.2 \mathrm{x}$ $10^{18}$ alpha decays per gram and a saturation swelling at high doses of $16 \%$. There is disagreement in the literature about the relative doses required to amorphize perovskite and zirconolite. There is some evidence that damage in natural perovskite anneals more rapidly than that in zirconolite. Since this mineral is not designed to be present in the current formulation, a detailed discussion of its radiation damage behavior is not presented.

\section{Plutonium Oxide}

Plutonium oxide does not become metamict under irradiation, but it swells to a saturation value of about $1 \%$ because of stored radiationproduced defects (TURCOTTE, 1972; 1974; WEBER, 1984).

\section{Projection of Radiation Effects in Plutonium Immobilization Ceramic}

It seems clear from the above that if stored at temperatures near ambient, the major phases in plutonium immobilization ceramic will become fully amorphous in less than 1,000 years. If the ceramic is placed in a repository in which the temperature during a significant part of this period is elevated to as much as $250^{\circ} \mathrm{C}$, which is the approximate maximum currently under discussion, the time required to achieve complete amorphization can be expected to increase somewhat, but it will still occur well before 10,000 years.

If the ceramic is not tightly confined, it will undergo swelling as a result of radiation damage. If sufficient external space is available, it will probably swell by about 5.5 to $6 \%$. If it is tightly confined, the swelling will likely be absorbed by the porosity, because ceramics are capable of plastic 
deformation at low strain rates, and the continuing alpha decay will enhance atomic rearrangement.

It cannot be completely guaranteed that microcracking will not occur, but it is likely to be insignificant, for three reasons: (1) the candidate ceramic is dominated by a single phase, minimizing problems of differential swelling; (2) the dominant phase is pyrochlore, which has a cubic crystal structure and therefore swells isotropically, minimizing stresses resulting from anisotropic swelling; and (3) the fabrication process can be tailored to some degree to minimize the grain size, which minimizes stresses resulting from both differential and anisotropic swelling.

As the plutonium transmutes to uranium, it will be accommodated in the ceramic, because the $4+$ ions of these two species are similar in ionic radius. The helium resulting from alpha decay will be trapped in vacancies or in microvoids and much of it will probably remain there over geologic time periods.

When water eventually contacts the ceramic after it has been converted to the amorphous state, there will likely be leaching of nonnetwork ions $(\mathrm{Ca}, \mathrm{U}, \mathrm{Gd}$, and $\mathrm{Pu}$, in the order of decreasing leachability) from a very thin layer near the surface. As these ions are leached out, the residual titanium-oxygen network will transform into a protective layer of polycrystalline titanium oxide (anatase form) on the surface. When this layer is in place, it will reduce the rate of loss of non-network ions to very small values, limited by the very low solubility of titanium oxide in water. For example, the solubility of the rutile form of titanium oxide at room temperature and $\mathrm{pH}$ between $\mathrm{pH} 9$ and $\mathrm{pH} 10$ has been measured at 10-9 molal (ZIEMNIAK, 1993). The very low solubility of hafnium will also support this protective action.

The existence of natural mineral samples of the same phases that have been selected for the candidate ceramic, that are fully metamict and that have achieved ages in the billion-year range while substantially retaining their actinides is strong testimony of the long-term durability of the candidate ceramic.

*Work performed under the auspices of the Office of Fissile Material Disposition of the U.S. Department of Energy by Lawrence Livermore National Laboratory under Contract W-7405-ENG-48 


\section{REFERENCES}

BAYLISS, 1989--Bayliss, P., Mazzi, F., Munno, R., and White, T.J., "Mineral Nomenclature: Zirconolite," Mineral. Mag. 53, 565-9 (1989).

CHAKOUMAKOS, 1987--Chakoumakos, B.C., "Pyrochlore," McGraw-Hill Yearbook of Science and Technology, S.P. Parker, ed., McGraw-Hill, Inc., New York (1987), pp. 393-5.

CLINARD, 1984a--Clinard, F.W., Jr., Rohr, D.L., and Roof, R.B., "Structural Damage in a Self-Irradiated Zirconolite-Based Ceramic," Nucl. Inst. and Meth. in Phys. Res. B1, 581-6 (1984).

CLINARD, 1984b--Clinard, F.W., Jr., "Self-Irradiation Effects in $238 \mathrm{Pu}-$ Substituted Zirconolite, I. Temperature Dependence of Damage," J. Nucl. Mater. 126, 245-54 (1984).

CLINARD, 1985--Clinard, F.W., Jr., Livak, R.J., Hobbs, L.W., and Rohr, D.L., "Structural Changes in $238 \mathrm{Pu}-$ Substituted Zirconolite on Recovery from the Metamict State," Mater. Res. Soc. Proc., vol. 50, Scientific Basis for Nuclear Waste Management IX, L.O. Werme, ed., Materials Research Society, Pittsburgh, PA, pp. 371-8 (1985).

CLINARD, 1986a--Clinard, F.W., Jr., and Hobbs, L.W., "Radiation Effects in Non-Metals," Chapter 7 of Physics of Radiation Effects in Crystals, R.A. Johnson and A.N. Orlov, eds., Elsevier, New York (1986), pp. 387-470.

CLINARD, 1986b--Clinard, F.W., Jr., "Review of Self-Irradiation Effects in Pu-Substituted Zirconolite," Ceramic Bulletin 65, 1181-7 (1986).

CLINARD, 1991--Clinard, F.W., Jr., Foltyn, E.M., and Ewing, R.C., "Stored Energy in Natural Zirconolite and Its Synthetic Counterpart After Alpha Recoil Self-Irradiation Damage," J. Nucl. Mater. 185, 202-7 (1991). 
DICKSON, 1989--Dickson, F.J., Hawkins, K.D., and White, T.J., "Calcium Uranium Titanate--A New Pyrochlore," J. Solid State Chem. 82, 146-50 (1989).

EWING, 1983--Ewing, R.C., and Headley, T.J., "Alpha-Recoil Damage in Natural Zirconolite $\left(\mathrm{CaZrTi}_{2} \mathrm{O}_{7}\right)$," J. Nucl. Mater. 119, 102-9 (1983).

EWING, 1987--Ewing, R.C., Chakoumakos, B.C., Lumpkin, G.R., and Murakami, T., "The Metamict State," MRS Bulletin, May 16/June 15, 1987, pp. 58-66.

EWING, 1988--Ewing, R.C., Chakoumakos, B.C., Lumpkin, G.R., Murakami, M., Greegor, R.B., and Lytle, F.W., "Metamict Minerals: Natural Analogues for Radiation Damage Effects in Ceramic Nuclear Waste Forms," Nucl. Instr. and Meth. in Phys. Res. B32, 487-97 (1988).

EWING, 1992--Ewing, R.C., and Wang, L.M., "Amorphization of Zirconolite: Alpha-Decay Event Damage Versus Krypton Ion Irradiation," Nucl. Inst. and Meth. in Physics Res. B65, 319-23 (1992).

EWING, 1995--Ewing, R.C., Weber, W.J., and Clinard, F.W., Jr., "Radiation Effects in Nuclear Waste Forms for High-Level Radioactive Waste," Prog. in Nucl. Energy 29, 63-127 (1995).

EYAL, 1982--Eyal, Y."Isotopic Fractionation of Thorium and Uranium upon Leaching of Monazite: Alpha-recoil Damage Effects," Scientific Basis for Nuclear Waste Management V, Materials Research Society, p. 399 (1982).

FARGES,1997--Farges, F., "Fivefold-Coordinated $\mathrm{Ti}^{4+}$ in Metamict Zirconolite and Titanite: A New Occurrence Shown by Ti K-Edge XANES Spectroscopy," Amer. Mineral. 82, 44-50 (1997).

FOLTYN, 1985--Foltyn, E.M., Clinard, F.W., Jr., Rankin, J., and Peterson, D.E., "Self-Irradiation Effects in $238 \mathrm{Pu}-$ Substituted Zirconolite: II. Effect of Damage Microstructure on Recovery," J. Nucl. Mater. 136, 97-103 (1985). 
GENERAL ELECTRIC, 1996--Nuclides and Isotopes, Fifteenth Edition, Chart of the Nuclides, Revised by J. R. Parrington et al., GE Nuclear Energy, San Jose, CA (1996).

GREEGOR, 1985a--Greegor, R.B., Lytle, F.W., Chakaoumakos, B.C., Lumpkin, G.R., and Ewing, R.C., "An Investigation of Uranium L-Edges of Metamict and Annealed Betafite," Mater. Res. Soc. Proc., vol. 50, Scientific Basis for Nuclear Waste Management IX, L.O. Werme, ed., Materials Research Society, Pittsburgh, PA (1985), pp. 387-92.

GREEGOR, 1985b--Greegor, R.B., Lytle, F.W., Chakoumakos, B.C., Lumpkin, G.R., and Ewing, R.C., "An Investigation of Metamict and Annealed Natural Pyrochlores by X-Ray Absorption Spectroscopy," Mater. Res. Soc. Proc., vol. 44, Scientific Basis for Nuclear Waste Management VIII, C.M. Jantzen, J.A. Stone, and R.C. Ewing, eds., Materials Research Society, Pittsburgh, PA (1985), pp. 655-62.

GREEGOR, 1987--Greegor, R.B., Lytle, F.W., Chakoumakos, B.C., Lumpkin, G.R., Ewing, R.C., Spiro, C.L., and Wong, J., "An X-Ray Absorption Spectroscopy Investigation of the Ta Site in Alpha-Recoil Damaged Natural Pyrochores," Mater. Res. Soc. Proc., vol. 84, Scientific Basis for Nuclear Waste Management X, J.K. Bates and W.B. Seefeldt, eds., Materials Research Society, Pittsburgh, PA (1987), pp. 645-58.

HART, 1996--Hart, K.P., Lumpkin, G.R., Giere, R., Williams, C.T., McGlinn, P.J., and Payne, T.E., "Naturally-Occurring Zirconolites--Analogues for the LongTerm Encapsulation for Actinides in Synroc," Radiochimica Acta , (1996).

HEINRICH, 1958--Heinrich, E.W., Mineralogy and Geology of Radioactive Raw Materials, McGraw-Hill, New York (1958), pp. 49-51, 256-65.

HEWETT, 1957--Hewett, D.F., Stone, J., and Levine, H., "Brannerite from San Bernardino County, California", Amer. Mineral. 42, 30-38 (1957). 
HOBBS, 1994--Hobbs, L.W., Clinard, F.W., Jr., Zinkle, S.J., and Ewing, R.C., "Radiation Effects in Ceramics," J. Nucl. Mater. 216, 291-321 (1994).

JOSTSONS, 1994--Jostsons, A, "Status of Synroc Development," Proc. of the 9th Pacific Basin Nuclear Conference, Sydney, Australia, 1-6 May 1994, National Conference Publication No. 94/6, Australian Nuclear Assn. Inc. and The Institution of Engineers, Australia.

KAIMAN, 1961--Kaiman, S., "Synthesis of Brannerite,", Canad. Mineral. 6, 389-90 (1957-61).

KESSON, 1983--Kesson, S.E., and Ringwood, A.E., "Safe Disposal of Spent Nuclear Fuel," Rad. Waste Man. and the Nucl. Fuel Cycle 4, 159-74 (1983).

KRANE, 1988--Krane, K.S., Introductory Nuclear Physics, Wiley, New York (1988), p. 195.

LEDERER, 1978--Lederer, C.M., and Shirley, V.S., eds., Table of Isotopes, Seventh Edition, John Wiley, New York (1978).

LEJUS, 1966--Lejus, A-M., Goldberg, D., and Revcolevschi, A., "Sur Quelques Composes Nouveaux Formes par le Rutile TiO2, avec des Oxydes de Metaux Trivalents et Tetravalents," Comptes Rendes Acad. Sci. Paris 263, serie C, 1223-6 (1966).

LUMPKIN, 1980--Lumpkin, G.R., and Ewing, R.C., "Alpha-Decay Damage in Minerals of the Pyrochlore Group," Phys. Chem. Minerals 16, 2-20 (1980).

LUMPKIN, 1985--Lumpkin, G.R., and Ewing, R.C., "Natural Pyrochlores: Analogues for Actinide Host Phases in Radioactive Waste Forms," Mater. Res. Soc. Proc,. vol. 44, Scientific Basis for Nuclear Waste Management VIII, C.M. Jantzen, J.A. Stone, and R.C. Ewing, eds., Materials Research Society, Pittsburgh, PA (1985), pp. 647-54. 
LUMPKIN, 1986a--Lumpkin, G.R., and Ewing, R.C., "High-Resolution Transmission Electron Microscopy of Microlite from the Harding Pegmatite, Taos County, New Mexico," Microbeam Analysis-1986, San Francisco Press, San Francisco, CA (1986), pp. 145-7.

LUMPKIN, 1986b--Lumpkin, G.R., Chakoumakos, B.C., and Ewing, R.C., "Mineralogy and Radiation Effects of Microlite from the Harding Pegmatite, Taos County, New Mexico," Amer. Mineral. 71, 569-88 (1986).

LUMPKIN, 1986c--Lumpkin, G.R., Ewing, R.C., et al., "Alpha-Recoil Damage in Zirconolite ( $\left.\mathrm{CaZrTi}_{2} \mathrm{O}_{7}\right)$," J. Mater. Res. 1, 564-576 (1986).

LUMPKIN, 1986d--Lumpkin, G.R., Foltyn, E.M., and Ewing, R.C., "Thermal Recrystallization of Alpha-Recoil Damaged Minerals of the Pyrochlore Structure Type," J. Nucl. Mater. 139, 113-20 (1986).

LUMPKIN, 1987--Lumpkin, G.R., and Ewing, R.C., "Transmission Electron Microscopy of Alpha-Decay Damage and Alteration of Betafite," Proc. of the 45th Ann. Mtg. of the Electron Micros. Soc. of America, G.W. Bailey, ed., San Francisco Press, Inc., San Francisco, CA (1987), pp. 376-7.

LUMPKIN, 1988a--Lumpkin, G.R., and Ewing, R.C., "Alpha-Decay Damage and the Aperiodic Structure of Pyrochlore," Proc. of the 46th Ann. Mtg. of the Electron Micros. Soc. of America, G.W. Bailey, ed., San Francisco Press, Inc., San Francisco, CA (1988), pp. 470-1.

LUMPKIN, 1988b--Lumpkin, G.R., and Ewing, R.C., "Preferential Leaching and Natural Annealing of Alpha-Recoil Tracks in Metamict Betafite and Samarskite," J. Mater. Res. 3, 357-368 (1988).

LUMPKIN, 1989--Lumpkin, G.R., and Ewing, R.C., "Alpha-Decay Damage and Annealing Effects in Natural Pyrochlores: Analogues for Long-Term Radiation Damage Effects in Actinide, Pyrochlore Structure Types," Mater. Res. Soc. Proc., vol. 127, Scientific Basis for Nuclear Waste Management XII, W. Lutze and R.C. Ewing, eds., Materials Research Society, Pittsburgh, PA (1989), pp. 253-60. 
LUMPKIN, 1992--Lumpkin, G.R., and Ewing, R.C., "Geochemical Alteration of Pyrochlore Group Minerals: Microlite Subgroup," Amer. Mineral. 77, 17988 (1992).

LUMPKIN, 1994--Lumpkin, G.R., Hart, K.P., McGlinn, P.J., and Payne, T.E., "Retention of Actinides in Natural Pyrochlores and Zirconolites," Radiochimica Acta 66/67, 469-74 (1994).

LUMPKIN, 1995--Lumpkin, G.R., Smith, K.L., et al., "Prediction of the LongTerm Performance of Crystalline Nuclear Waste Form Phases from Studies of Mineral Analogues," Proc. of the 9th Pacific Basin Nuclear Conference, Sydney, Australia, 1-6 May 1994, National Conference Publication No. 94/6, Australian Nuclear Assn. Inc. and The Institution of Engineers, Australia. Lumpkin, G.R., and Ewing, R.C., "Geochemical Alteration of Pyrochlore Group Minerals: Pyrochlore Subgroup," Amer. Mineral. 80, 732-43 (1995).

LUMPKIN, 1996--Lumpkin, G.R., and Ewing, R.C., "Geochemical Alteration on Pyrochlore Group Minerals: Betafite Subgroup," Amer. Mineral. 81, 123748 (1996).

MAZZI, 1983--Mazzi, F., and Munno, R., "Calciobetafite (New Mineral of the Pyrochlore Group) and Related Minerals from Campi Flegrei, Italy; Crystal Structures of Polymignyte and Zirkelite: Comparison with Pyrochlore and Zirconolite," Amer. Mineral. 68, 262-76 (1983).

MITAMURA, 1992--Mitamura, H., Matsumoto, S., Hart, K.P., Miyazaki, T., Vance, E.R., Tamura, Y., Togashi, Y., and White, T.J., "Aging Effects on Curium-Doped Titanate Ceramic Containing Sodium-Bearing High-Level Nuclear Waste," J. Am. Ceram. Soc. 75, 392-400 (1992).

OVERSBY, 1981--Oversby, V.M., and Ringwood, A.E., "Lead Isotopic Studies of Zirconolite and Perovskite and Their Implications for Long Range Synroc Stability," Rad. Waste Man. 1, 289-307 (1981). 
PABST, 1954--Pabst, A., "Brannerite from California," Amer. Mineral. 39, 109-117 (1954).

PATCHETT, 1960--Patchett, J.E., and Nuffield, E.W., "Studies of Radioactive Compounds X--The Synthesis and Crystallography of Brannerite," Canadian Mineral. 6, 483-90 (1960).

REEVE, 1991--Reeve, K.D., "SYNROC--A High Quality Nuclear Waste Form," Ceramics Today--Tomorrow's Ceramics, Proc. of the 7th Intl. Meeting on Modern Ceramics Technologies, World Ceramics Congress,, Montecatini Terme, Italy, 24-30 June, 1990, Part D, edited by P. Vincenzini, pp. 311120, Elsevier, New York (1991).

RINGWOOD, 1988--Ringwood, A.E., Kesson, S.E., Reeve, K.D., Levins, D.M., and Ramm, E.J., "Synroc," Chapter 4 in Radioactive Waste Forms for the Future, W. Lutze and R.C. Ewing, eds., North-Holland, New York (1988), pp. 233334.

ROBERTS, 1974--Roberts, W.L., Rapp, G.R., Jr., and Weber, J., Encyclopedia of Minerals, Van Nostrand, New York (1974), p. 85.

RYERSON, 1983--Ryerson, F.J., "Microstructure and Mineral Chemistry of Synroc-D," J. Amer. Ceram. Soc. 66, 629-36 (1983).

SINCLAIR, 1981--Sinclair, W., and Ringwood, A.E., "Effects of Nuclear Radiation on the Crystal Structures of Zirconolite and Perovskite," Geochem. J. 15, 229 (1981).

SMITH, 1992--Smith, K.L., Lumpkin, G.R., Blackford, M.G., Day, R.A., and Hart, K.P., "The Durability of Synroc," J. Nucl. Mater. 190, 287-94 (1992).

SMITH, 1993--Smith, K.L., and Lumpkin, G.R., "Structural Features of Zirconolite, Hollandite, and Perovskite, the Major Waste-Bearing Phases in Synroc," Defects and Processes in the Solid State: Geoscience Applications, The McLaren Volume, J.N. Boland and J.D. Fitz Gerald, eds., Elsevier, New York (1993), pp. 401-22. 
SMITH, 1996--Smith, K.L., Zaluzec, N.J., and Lumpkin, G.R., "In situ Studies of Ion Irradiated Zirconolite, Pyrochlore, and Perovskite," submitted to J. Nucl. Mater. in 1996.

SOLOMAH, 1987--Solomah, A.G., Richardson, P.G., and McIlwain, A.K., "Phase Identification, Microstructural Characterization, Phase Microanalyses and Leaching Performance Evaluation of Synroc-FA Crystalline Ceramic Waste Form," J. Nucl. Mater. 148, 157-65 (1987).

TURCOTTE, 1972--Turcotte, R. P., and Chikalla, T.D., "Self-Radiation Damage in ${ }^{238} \mathrm{PuO}_{2}$," BNWL-B-225, Battelle Pacific Northwest Laboratories, Richland, WA (October 1972).

TURCOTTE, 1974--Turcotte, R.P., and Chikalla, T.D., "Concentrated Defects in $\mathrm{PuO}_{2}$," Defects and Transport in Oxides, M.S. Seltzer and R.I. Jaffee, eds., Plenum Press, New York (1974), pp. 159-73.

VAN KONYNENBURG, 1983--Van Konynenburg, R.A.. and Guinan, M.W., "Radiation Effects in Synroc-D," Nucl. Technol. 60, 206-17 (1983).

VANCE, 1994--Vance, E.R., Ball, C.J., Day, R.A., Smith, K.L., Blackford, M.G., Begg, B.D., and Angel, P.J., "Actinide and Rare Earth Incorporation into Zirconolite," J. of Alloys and Compounds 213/214, 406-9 (1994).

WALD, 1982--Wald, J.W., and Offermann, P., "A Study of Radiation Effects in Curium-Doped $\mathrm{Gd}_{2} \mathrm{Ti}_{2} \mathrm{O}_{7}$ (Pyrochlore) and CaZrTi2O7 (Zirconolite)," $\underline{\text { Scientific }}$ Basis for Nuclear Waste Management V, W. Lutze, ed., Elsevier, New York (1982), pp. 369-78.

WALD, 1984--Wald, J.W., and Weber, W.J., "Effects of Self-Radiation Damage on the Leachability of Actinide-Host Phases," Advances in Ceramics, Vol. 8, Nuclear Waste Management, The American Ceramic Society (1984), pp. 715 . 
WEBER, 1984--Weber, W.J., "Alpha-Irradiation Damage in $\mathrm{CeO}_{2}, \mathrm{UO}_{2}$, and $\mathrm{PuO}_{2}$," Radiation Effects 83, 145-156 (1984).

WEBER, 1985--Weber, W.J., Wald, J.W., and Matzke, Hj., "Self-Radiation Damage in $\mathrm{Gd}_{2} \mathrm{Ti}_{2} \mathrm{O}_{7}$," Mater. Letts. 3, 173-80 (1985).

WEBER, 1986--Weber, W.J., and Wald, J.W., "Effects of Self-Radiation Damage in Cm-Doped $\mathrm{Gd}_{2} \mathrm{Ti}_{2} \mathrm{O}_{7}$ and $\mathrm{CaZrTi}_{2} \mathrm{O}_{7}$," J. Nucl. Mater. 138, 196-209 (1986).

WEBER, 1992--Weber, W.J., Hess, N.J., and Maupin, G.D., "Amorphization in $\mathrm{Gd}_{2} \mathrm{Ti}_{2} \mathrm{O}_{7}$ and $\mathrm{CaZrTi}_{2} \mathrm{O}_{7}$ Irradiated with $3 \mathrm{MeV}$ Argon Ions," Nucl. Instr. and Meth. in Physics Research B65, 102-6 (1992).

WHITE, 1995--White, T.J, Ewing, R.C., Wang. L.M., Forrester, J.S., and Montross, C., "Temperature Dependence of Amorphization for Zirconolite and Perovskite Irradiated with $1 \mathrm{MeV}$ Krypton Ions," Scientific Basis for Nuclear Waste Management XVIII, Part 2, Mater. Res. Soc. Proceedings, vol. 353, 1413-20, T. Murakami and R.C. Ewing, eds. , Materials Research Society, Pittsburgh, PA (1995).

ZIEMNIAK, 1993--Ziemniak, S.E., Jones, M.E., and Combs, K.E.S., "Solubility Behavior of Titanium (IV) Oxide in Alkaline Media at Elevated Temperatures," J. Solution Chem., 22, 601-23 (1993). 


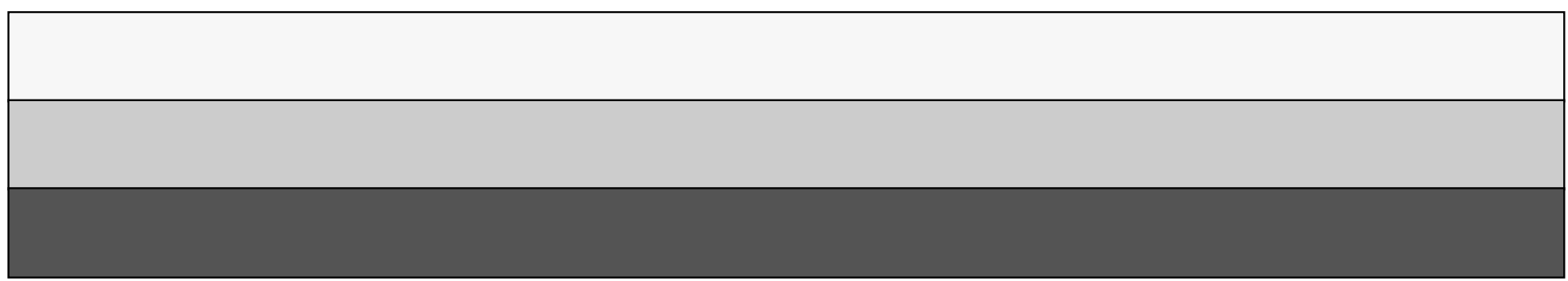

